\title{
What's it got to do with the price of bread? Condorcet and Grouchy on freedom and unreasonable laws in commerce
}

European Journal of Political Theory 2018, Vol. 17(4) 432-448

(C) The Author(s) 2018

Article reuse guidelines: sagepub.com/journals-permissions DOI: |0.1 I77/|474885 | |878239| journals.sagepub.com/home/ept

@SAGE

\section{Sandrine Bergès}

Bilkent University, Turkey

\begin{abstract}
István Hont identified a point in the history of political thought at which republicanism and commercialism became separated. According to Hont, Emmanuel Sieyès proposed that a monarchical republic should be formed. By contrast the Jacobins, in favour of a republic led by the people, rejected not only Sieyès's political proposal, but also the economic ideology that went with it. Sieyès was in favour of a commercial republic; the Jacobins were not. This was, according to Hont, a defining moment in the history of political thought. In this article, I offer a different analysis of that particular moment in the history of the commercial republic, one that instead of focusing on Sieyès and the Jacobins, looks at the thought of Girondins philosophers Nicolas de Condorcet and Sophie de Grouchy. I argue that their arguments provide sound models for a commercial republic, reconciling late 18 th century republican ideals in which virtue was central, with the need for a flourishing and internationally active market economy.
\end{abstract}

\section{Keywords}

Condorcet, De Grouchy, French Revolution, history of political thought, Istvan Hont, Jacobins, Sieyès

\section{French revolutionary republicans}

In Jealousy of Trade, István Hont (2005) identified a point in the history of political thought at which republicanism and commercialism became separated. Emmanuel Sieyès, the cleric who was the prime mover behind the creation of the Assemblée constituante of 1789 and the drafting of the ensuing Constitution, proposed that a monarchical republic should be formed. The Jacobins, in favour of a republic led

\section{Corresponding author:}

Sandrine Bergès, Department of philosophy, Bilkent University, Bilkent, Ankara 06800, Turkey.

Email: berges@bilkent.edu.tr 
by the people, rejected not only Sieyès's political proposal but also the economic ideology that went with it. Sieyès was in favour of a commercial republic; the Jacobins were not. This was, according to Hont, a defining moment in the history of political thought.

In this article, I wish to offer a different analysis of that particular moment in the history of the commercial republic, one that instead of focusing on Sieyès and the Jacobins, looks at the thought of Girondins philosophers Nicolas de Condorcet and Sophie de Grouchy. I shall argue that their arguments provide sound models for a commercial republic, reconciling late 18th century republican ideals, in which virtue was central, to the needs for a flourishing and internationally active market economy.

As Hont makes clear in Jealousy of Trade (Hont, 2005: 8, 23, 29) and in Politics in Commercial Society (Hont, 2015: 44, 70, 76, 89), republican theories have undergone many transformations since their Roman and Athenian manifestations. From Machiavelli's strong emphasis on war and trade, to the creation of Italian Renaissance republics which had little to do with democracy (Hont, 2015: 83; Hont, 2005: 9), to Montesquieu's emphasis on the rule of law and his view that a republic was not necessarily tied to one form of government but could in principle be a monarchy (Hont, 2005: 33, 134; Hont, 2015: 44), to Rousseau's rural republicanism, to the sort of republicanism that emphasizes liberty and freedom from domination, such as that of Condorcet and Paine. Even during the period I am here concerned with - the French Revolution - Hont (2005: 134) notes that there was much disagreement as to what kind of theory republicanism was supposed to be $-\mathrm{a}$ concern for the public good, or a form of government?

The two republican philosophers I am considering, Nicolas de Condorcet and Sophie de Grouchy, have recently come under the scrutiny of contemporary political philosophers. Condorcet's political writings were brought into focus by a new edited volume in the Cambridge Texts in the History of Political Thought (Lukes and Urbinati, 2012). The editors of that volume highlight, but do not discuss, Condorcet's role in republican theory, claiming in particular that he defended a view of freedom as non-domination, by which he meant dependence on any sort of arbitrary power:

By a free man we mean one who is not subject in any of his private activities to the arbitrary will of an individual, so that free is opposed to slavery or serfdom, depending on the nature of this subjection, and consequently, to any one who is subject to the arbitrary will of a despot, a senate, or any other association of individuals. (Condorcet, in Schandeler and Crépel, 2004: 553-554)

Condorcet was also an early supporter of commercial republicanism, that is, he was concerned not only with freedom as non-domination, but with allowing the (controlled) growth of the market insofar as these were compatible. He developed these ideas, together with his wife and collaborator, Sophie de Grouchy. Grouchy, a philosopher in her own right, is known for her Letters on Sympathy (Bernier and Dawson, 2014), a response to Adam Smith's Theory of Moral Sentiments which she 
published at the same time as her translation of that text into French. ${ }^{1}$ We know that she wrote more ${ }^{2}$ - but are not aware of any other texts published in her name. I have previously argued that some of the articles published in a paper edited by Condorcet in the summer of 1792, Le Républicain, were either written or co-written by Grouchy (Bergès, 2015). In those texts, and also in Grouchy's Letters, we find the early development of a commercial republican theory.

It is not surprising that both Condorcet and Grouchy wrote about the place of the market in the republic, as the debate as to whether republicans should take into account economic factors was very much alive in France at the end of the 18th century. While some revolutionary republican factions privileged a certain kind of isolationism, others thought that the future of the French republic depended on economic exchanges with the rest of the world. Condorcet and Grouchy were very much part of the latter group and, in the writings I examine here, their joint belief in a commercial republic is explored and defended through the republican concepts of liberty as non-domination, the rule of law and the pervasive corrupting effect of arbitrary power on people, states and institutions, but also on the economy of a state.

In what follows I will make a case for the importance of paying attention to Condorcet and Grouchy's writings in debates about commercial republicanism, by which I understand the view that a republic is not only compatible with a commercial society, but that it will thrive best if free commerce is allowed, both internally and externally. In the next section I will offer a survey of 18 th century discussions of commercial societies and republicanism, emphasizing that the debate progressed beyond Sieyès's disagreement with Paine, which is central to Hont's analysis.

In the third section I will introduce and discuss Condorcet's arguments for republican commercialism, arguing that for him non-domination is a condition of freedom in markets as in individuals. I will show how both his and Grouchy's political writings about the revolution in Le Républicain develop this view further, arguing that arbitrary power has a financial as well as a moral cost. In the fourth section, I will show that in Letter VII of her Letters on Sympathy, Grouchy develops a republican account of laws that is designed to free the economy at the same time as it re-establishes justice. I conclude, in the fifth section, that the Condorcet/ Grouchy account of commercial republicanism is valuable especially because it derives its economic and political reforms from the same republican principles.

\section{Is late I 8th century commercial republicanism a conflicted position?}

Contemporary neo-republicanism has been accused of failing to address economic concerns, and in particular of implicitly writing off the market as incompatible with the sort of civic virtues that republicanism demands (Gaus, 2003; Laborde and Maynor, 2008: 20-21). This is a criticism that leading republican philosophers have been keen to defend themselves against, arguing that republicanism treats economic concerns and the market exactly as it does other areas of life: by making 
sure that it does not interfere with the values of political equality and freedom from domination (Dagger, 2006; Pettit, 2006, 2013). This entails that the market must be regulated, but not necessarily in a manner that makes it 'unfree'. On the contrary, contemporary republicans value the market for its utility, i.e. because it promotes independence via private property and therefore diminishes the power of the richer classes to dominate the poorer ones. Philip Pettit, for instance, has argued that:

It will appeal, in particular, for the way it can respect people's undominated standing in relation to one another, allowing them to exchange things on a noncoercive basis. Indeed, it may also strengthen this standing, reinforcing it as a result of facilitating its exercise and recognition. (Pettit, 2006: 147)

But although a market-based economy means that people's choices are less restricted, and that they are not in any case restricted by a third party who might be said to dominate them, neo-republican sceptics might still want to distance themselves from a market-driven economy on the grounds that it is detrimental to civic virtue. This prejudice against the possibility of commercial republicanism can be traced to the economic and political thought that arose during the French Revolution. Market economies tend to awaken the sort of base and selfish instincts that are not conducive to the development of civic virtues, and that are therefore inimical to the sort of republicanism held in the late 18 th century.

Another way of putting it is that republicans may not be comfortable with commercialism's apparent neutrality with respect to virtue: something being economically worthwhile is not incompatible with its being morally distasteful. Republicans in the 18th century believed that some virtues were central to the political arrangements they thought to be legitimate - and these virtues could be threatened by a strong interest in increasing one's personal wealth, opening the door to corruption both of individual characters and of society in general. So Fénelon and Rousseau, for instance, both blamed Colbert's very active commercial policies for the degeneration of healthier, rural populations. ${ }^{3}$ But republicans may also believe that commercialism is at times incompatible with liberty understood as non-domination. A free market might appear to be at least in principle compatible with one class of people dominating another. For instance, in an unregulated economy, those who cannot afford medicine to save their lives are at the mercy of pharmaceutical companies who sell them in an unregulated market, or one that is regulated (somewhat arbitrarily) by the patent system.

The 18th century was divided when it came to the value of commerce. Pocock (1972) suggests that in England, at least, those with republican allegiances felt that commerce was the root of corruption, and therefore inimical to republican virtues. ${ }^{4}$ In France, there was a sense that the international commercial policies of Colbert had corrupted the people and the nation, bringing about an obsession for luxury over and above a concern for real needs on the one hand, and privileging urban pursuits over the more necessary agricultural ones, leading to a decline in the rural population (Hont, 2005: 25). 
Yet this represents only one strand of reactions, to one manifestation of commercial society - i.e. the rural republican response to Colbert. Some French republicans, however, were not only less distrustful of commercial society, but also felt that it was necessary for the survival and growth of the republic. Hont (2005) argued that republicanism and commercialism had been philosophical companions until 18th century French political thinkers forced a distance between them when they asked what a republic might look like in the aftermath of the Revolution. Sieyès, Hont claims, proposed a republican ideal that was open to commerce, one that would ensure that only those who participate in commercial exchanges through their labour are part of the processes that lead to the drafting of regulation. In such a system, there would be little room for abuse of power by aristocrats at the expense of peasants and artisans, and the market would in fact serve to abolish the hierarchy of the ancien régime (Hont, 2005: 134).

Unfortunately, Hont goes on to say, Sieyès's views encountered strong resistance from those who eventually established themselves as the leaders of the Revolution, the Jacobins. This was not primarily because they rejected the republic as a form of commercial society, but because Sieyès's brand of republicanism was too close to the monarchical system, and not close enough to direct democracy (Hont, 2005: 135). Indeed, Sieyès believed that monarchy could be republican as long as it existed for the good of the people (Hont, 2005: 132), following Montesquieu's claim that a republic is not a specific form of government, but simply the rule of law, which can be protected by any individual or group of individuals that is ruling in the interest of all, rather than their own. For Hont, it seems, the Jacobins' reluctance to embrace commercialism derives from their opposition to Sieyès on the one hand, and their general opposition to modernity on the other (Hont, 2005: 135). Perhaps it also derived from their allegiance to Rousseau, who advocated a rural form of republicanism, where the people proudly laboured the soil of their country, providing for the needs of citizens while nurturing patriotism: '[p]easants are much more attached to their soil than are townsmen to their city'. He also believed that peasants were more likely to be patriotic and to put in the work necessary for defending country and constitution. A reliance on agriculture more than on financial power, he said, equates work with freedom in the sense that peasants who produce the food they need to live are independent of external powers (Rousseau, 1765: 10).

The Jacobins were not, however, the only Revolutionary thinkers to reject Sieyès's understanding of the republic. One of his strongest philosophical opponents, Thomas Paine, associated with the Girondins more than the Jacobins, objected to Sieyès's proposal for a republican monarchy. As monarchy always meant the absolute power of one individual, Paine said, it was also always potentially tyrannical, as it depended on the unknown character of the individual in question (Condorcet and Paine, 1991 [1791]: 1, 8 and 3, 52-53).

Although Paine, Condorcet, Brissot and other Girondins did object to Sieyès's brand of republicanism, they were also known for defending a 'commercial' type of republicanism, modelled on a perception of American republicanism. In this they were opposed to the Jacobins and the Cordeliers (Desmoulins's club) who felt that 
republicans should prioritize the question of how to make a large nation like France into a democracy, and that this would be best achieved by maintaining a rural, self-sustaining economy (Hammersley, 2005: 54). The Cordelier's republicanism seems to have been closer to Rousseau's own, in the sense that Rousseau's love of the ideal republics of the ancient world, and his rural republicanism, were fundamentally inimical to commercial interests. However, even this interpretation of a historical divide between commercial and rural republicans is questionable. Hont, when discussing the so-called Adam Smith problem, explained how this approach to Rousseau is misguided, and more generally debunked the idea that to be a republican in the 18 th century is to be fundamentally opposed to commercial society. ${ }^{5}$ But at the same time, he argued that republican attempts at reconciling politics and commerce were potentially highly paradoxical, as they involved a dual and sometimes incompatible focus on the desire to preserve national values and virtues, while opening up the nation to the influence of foreign values (or lack thereof) through the mechanism of large scale cross-border material exchange.

But if the conflict between commercialism and republicanism is essentially a conflict between economic and moral growth, then it is unclear that we should be able to see this conflict reflected in a comparison between Rousseau's republicanism and Smith's commercialism, as Hont (2015: 70) claims. Affective sentiment, the propensity to compare oneself and one's emotional or physical responses to pain and pleasure to that of others, is central both to Smith's commercialism and Rousseau's republicanism. For Rousseau, pity for our fellow beings eventually leads us to develop morality, and for Smith, sympathy eventually also leads to competition, the leading principle of commercialism. As one of Hont's reviewers puts it:

\begin{abstract}
Comparison can be benign, in the sense that it sometimes takes the form of standing back from our immediate or self-regarding desires and measuring them impartially alongside the desires of other people (or of ourselves in the future), but it can also be malign, in that it gives us the motive for emulation and domination. But, Smith argued, even this malign form will, in the appropriate structures, lead to a benign result, through (for example) competitive behaviour in a market. (Tuck, 2016)
\end{abstract}

That Rousseau's republicanism and Smith's commercialism are both drawn from the principle that we care about each other's emotions at least suggests that their views might have more in common than is generally supposed. One might further formulate the hypothesis that although Hont might be right that there are tensions between Rousseau's own brand of republicanism and a desire to embrace commercial society, and that this tension was inherited by some republican factions of the French Revolution, this need not exclude other forms of republicanism in the period from embracing commercialism. Indeed, the arguments put forward by Nicolas de Condorcet and Sophie de Grouchy do exactly this. Their views on competition and virtue are inextricably tied to core aspects of the republican tradition: in particular, that market tyranny is bad because it is domination, and because it freezes both the economy and the moral growth of a nation. 
On Condorcet and Grouchy's accounts, republicans cannot afford to over-regulate the market.

\section{Condorcet's argument in Le Commerce des Blés}

The account I am focusing on here is offered by Condorcet and Grouchy, a husband and wife team who defended republicanism before the beginning of the French revolution. Condorcet and Grouchy's joint belief in a commercial republic is reflected in Condorcet's (1776) discussion of the pricing of wheat, their joint discussions of the 'cost' of tyranny (Condorcet and Paine, 1991 [1791]) and Grouchy's discussion of the role of law in regulating commerce in her Letters on Sympathy (Bernier and Dawson, 2014).

Nicolas de Condorcet, mathematician, economist and philosopher, was first appointed as inspector general of the mint by Turgot in 1774 and remained there even after Turgot was dismissed and replaced by Necker in 1776, and until 1791. In 1786, he married Sophie de Grouchy and the two worked closely together until Condorcet's death in 1794, reading and commenting on each other's work, and even collaborating in the production of a short-lived revolutionary paper, Le Républicain, in the summer of $1792 .{ }^{6}$ Condorcet's friend, mentor and superior, Turgot, who was Controller-General of Finance for Louis XVI, established free trade in grain in 1774. This was, however, unfortunately followed by a poor harvest in 1775, which resulted in famine and was followed by the infamous flour war, or wheat rebellion - revolts and riots against the rise of the price of wheat, and therefore bread. Partly because of this, and partly because of political disputes involving his successor Jacques Necker, Turgot was forced to resign in 1776. But Condorcet stayed in place at the Mint, and pursued a politics of the (relatively) free market. In 1776, he published a book arguing that state interference on the selling and buying of grain, such as was practiced in Old Regime France, was harmful not only to the economy, but to the social and moral wellbeing of the French people. The arguments he deployed in this piece built on those of Turgot's 1774 Reflections on the Formation and Distribution of Wealth, of which Condorcet wrote that it 'may well be considered as the germ of the treatise on the Wealth of Nations written by the celebrated Smith' (Groenewegen, 1969: 271).

It is unclear whether Smith had in fact read Turgot's book, or whether the similarities between the two arose simply because the two authors had a similar outlook on political economy, as well as a joint intellectual ancestry (Groenewegen, 1969: 287). In any case it is clear that the influence did not go the other way: Condorcet's own book came out at the same time as Smith's Wealth of Nations. There is, however, definitely a common ideological core in the works of Turgot, Condorcet and Smith. All three are opposed to government intervention in the commerce of grain, and Smith seems to adopt some of the exceptions suggested by Turgot, for instance that governments should intervene to ensure that employers pay workers in money, not in kind (Rothschild, 1992: 1205). All three were heavily critical of the Physiocrats, or Economists, who preceded Turgot (Rothschild, 2013: 36). And all three also decried the implementation of typical government 
intervention as oppressive, denouncing practices such as impromptu visits and searches of labourers' homes (Rothschild, 1992: 1209). ${ }^{7}$

Certainly in Condorcet's case, the argument against government intervention was motivated as least as much by concern over political and social wellbeing as it was by economic growth. In fact, it seems quite clear that as far as Condorcet is concerned, the economic is instrumental to the social and political. He concludes in part two of his book that: 'Thus, the liberty of grain commerce, by securing more sustenance for the people, and in a manner more equal and better suited to its faculties, will make the people greater, stronger, less degraded and less corrupt' ${ }^{8}$ In Le Commerce des Blés, published in the same year as The Wealth of Nations, Condorcet (1776) develops two main lines of argument based on the premise that the price of grain should not be controlled by the government. First, he argues that the condition of labourer or agriculturer will no longer be one to avoid, but one to enjoy and draw pride from. This will lead to healthier people, more respect for those who work the land (and hence more self-respect for them) and less crowding in the cities and palaces (where corruption happens). Second, he tells us that wealth will no longer be something to admire, to derive pride from, nor to seek at all costs. This will lead to less crime, less willingness to debase oneself and others in order to obtain money and thus more self-respect.

The first argument depends on a number of claims Condorcet makes about the dependence of the condition of labourers and farmers not only on wealth, but on the reputation they enjoy in the rest of society. If a labourer makes a living that enables him to be comfortable, then people will not rush out of their villages to take up servants' positions in the city, but will instead remain and develop the life and culture of the villages. Secondly, if agriculture is encouraged and protected by the government - enforcing better salaries instead of interfering in sales prices and production methods - those who work the land will appear more respectable, and the life of the land will become more attractive, say, than the life of an impoverished courtier, reduced to begging at court.

Condorcet's second argument relies on what he perceives as the consequences of a healthier economy. Money, he says, will no longer be regarded as exceptional if workers earn what they ought, and therefore will no longer inspire such extreme consideration. It follows also that differences in wealth will no longer serve to build a wall between the people and the aristocrats, as the latter will be less remarkable. A further set of consequences of having a wealthier class of labourers will be the end of the overcrowding of cities, which in turn will lead to less of the debauchery that is caused by people piling up in cities in order to escape the land. A decrease in the respect that is granted to wealth will also result in a decrease in the sort of corruption that arises from love of money, and that leads people to respect those who do not deserve it, and to associate with criminals in order to obtain it or to draw self-respect from it.

What is significant about Condorcet's arguments is that the consequences of governmental intervention in the form of laws that stifle the market are great inequalities in the distribution of wealth, and at the same time social and political corruption. This makes a great deal of sense if we focus on the aspect of 
interference that Condorcet objects to. He does not believe that the government should never interfere in commercial exchange: he believes on the contrary that it should protect the interests of those involved in the production and distribution of goods, so that they are not underpaid or overworked. But what he does object to is both oppressive laws that do not take into consideration the real welfare of those they apply to, and the arbitrary enforcement of these laws, which meant that inspectors could close a shop, or force a manufacturer to waste a batch of produce, or generally interfere with the lives of producers in ways that they could not predict.

As far as Condorcet was concerned, arbitrary interference has some very specific consequences on the wellbeing of those who are subject to it. In the case of producers or manufacturers who are subject to potential visits by inspectors, this means that they are less likely to put any effort into any sort of innovation - as this effort might lead to loss, they are less likely to care about treating those who work for them justly, as the regulations might not lend themselves to equity, and they are less likely to develop virtuous traits as employers or citizens because they cannot rely on being able to act according to their own judgment, so that any character trait they might have is on the whole irrelevant to the way in which they conduct their business.

Jean-Marie Roland de la Platière, who before he became Minister of the Interior during the revolution worked as the inspector of manufacturing, also observed first hand the detrimental effects on the economy of government interference: ${ }^{9}$

I have looked in vain for the kind of manufacturing rules that we should have in place for the good of the trade, I have read them all, I have meditated on this cold and heavy compilation, I have envisaged the effects, and followed up their consequences. I think they should all be abolished. (1778, Reply to Necker's Survey, in Reynolds, 2013: 36)

Roland himself had witnessed factories being closed, equipment being confiscated and individuals being bankrupted or put out of work for failing to comply with highly arbitrary and non-economically beneficial legislation. This led him to the conclusion that, on the whole, the laws that regulated manufacturing, instead of benefiting production, slowed it down, and at the same time contributed to lowering the morale and ambition of those who might otherwise help better the economy. In other words, his observations on manufacturing matched those of Condorcet and Turgot on the production of grain: the government's interference was merely a way of oppressing its subjects and reinforcing a politics of domination, and was in no way conducive to progress or development, whether economic or social.

Given the importance that the price of bread and the conditions of life of the farmers who produced the flour played at the beginning of the revolution (the 1789 riots were in a sense a replay of the 1775 flour wars), it is no surprise that economic considerations should be central to Condorcet's political arguments. This concern is also visible in Grouchy's works, i.e. her Letters on Sympathy and the articles she either wrote or co-wrote for Le Républicain. One of the main arguments in the 
short and satirical 'Letter from a Young Mechanic' is that the cost in taxes for building a mechanical, automated royal family would represent a fraction of the cost of the actual king. The author estimates the cost of producing a court of 200 machines, and the annual cost of maintaining the machines at half a denier per person. Moreover, this king will not constitute a danger to liberty, so the moral cost will be reduced also. The emphasis of the piece is on the role that domination plays both politically and economically. Grouchy uses the concept of 'cost' as a metaphor: a monarch takes something dear from us, namely our freedom, in exchange for a very limited service (such as could be performed by a robot!). But she also uses it literally: the wealth of a nation is badly affected by a king's unpredictability, and especially by the expenses they perform on a whim for a new ally or favourite (which is what the king's list amounted to). There are thus political, moral and financial costs associated with arbitrary power, and all are diminished when the king is gone.

In the first part of 'Observations on the King's Letter', published in the second issue of the journal, originally drafted by Etienne Dumont and rewritten by Grouchy, she observes that:

King's palaces are out of proportion with human nature; the greats of nations fulfill the vilest offices for them; citizens vilify themselves in their presence and become mere subjects; our imagination turns them into gods to adore, and to who we sacrifice human blood. For the brilliance of the throne, two hundred thousand men cut each other's throats. The crown's honour is the scourge of nations, and when kings talk of their glory, the earth is covered in mourning. (Condorcet and Paine, 1991 [1791]: 2: 27)

This passage emphasizes what Condorcet had already noted in his Commerce des Blés, namely that the real cost of the money lavished on the throne is a moral one, consisting of a loss of status and dignity for those who serve the king. Under a king, the author argues, those that would serve the nation through their greatness become mere lackeys; and those that would provide the workforce kill each other.

The author carries on the discussion by explaining that there is a proper expenditure in the service of a king, but that it is absurd to impoverish a nation merely in order to enrich its representative, and that this is what the current state of affairs in France is. The king's requirement for the continuation of his liste civile - that is an annual sum funded by taxes to support the royal family and their entourage in luxury - means that the king is not really willing to act as a paid servant of the state, but instead wishes to carry on ignoring the nation's interest. The financial abuse is a symptom here of political unfitness (Condorcet and Paine, 1991 [1791]: 3: 43).

What Grouchy's two articles in Le Républicain have in common with Condorcet's Commerce, and his general view that to be free means to be free from domination, is that they portray political freedom and economic health as being hampered by arbitrary power. The tying of the economic on the one hand and the moral and political on the other appears deliberate, and the articles are both evocative and rousing. But if we want to see an argument giving reasons why 
the two should be affected in the same way, we must turn to another text: Sophie de Grouchy's Letters on Sympathy.

\title{
Financial inequality and reasonable laws in the Letters on Sympathy
}

If the two articles of Le Républicain examined above mostly focus on the corrupting power of a rich monarch on the subjects surrounding him/her - the courtiers, and consequently those who work to provide for them, the servants and the peasants in the Letters on Sympathy, Grouchy is concerned with the power of laws to dominate, and the consequences that arbitrary laws have on the economy, but also on the moral wellbeing of a people: ${ }^{10}$

\begin{abstract}
But now we have conclusive evidence that lack of salary or insufficient salaries were caused nearly entirely by prohibitive laws hampering commerce and industry. Those laws, at the same time, were harming the wellbeing of all by collecting, little by little, in the hands of a few, wealth that then became in those hands a means of oppression, and which otherwise, through the free movement of interests would have remained if not equal, at least common to all. The unequal division of taxes at last overwhelmed the inferior class who, with no property and no liberty, was reduced to relying on fraud and would cheat remorselessly, because our conscience cannot survive when it is in chains. The incentive to behave unjustly, when it is based on need, is therefore extremely rare in the absence of bad laws, as even when they are present, this incentive is weak, its effects are the least widely spread and it is to be feared the least.
\end{abstract}

[...] But supposing we had reasonable laws, the temptation to steal in order to increase one's pleasures would be much weakened by the inconvenience that acting on it would cause, so that it would be in fact quite rare. (Bernier and Dawson, 2014: Letter 7$)^{11}$

The above passage is strongly reminiscent of Condorcet's argument in the Commerce des Blés: Grouchy claims that market freedom is tied not only to economic welfare but also to moral improvement. Those same laws that restrict commerce unnecessarily are also detrimental to public morality, as they encourage injustice. Were oppressive laws to become reasonable, very few, she says, would have any reason to commit an injustice for the sake of financial gain. But whereas Condorcet examines the mechanics of how the bad regulations in place at the time he is writing affect not only the price of bread but class relations and, generally, citizens' wellbeing and moral standing, Grouchy here offers an analysis of how bad laws are bound to have economic and moral consequences. In particular she reflects on the relationship between legislation and the moral psychology of domination - based on the premise that a government's laws may shape the way in which citizens relate to each other so as to strengthen its values. ${ }^{12}$ Grouchy is especially concerned that it is the experience of being subject to the arbitrariness of bad laws and institutions that forces citizens to act unjustly. 
Let us examine the passage more carefully. Grouchy claims that extreme financial inequality results in oppression of the poor by the rich. That is, it enables and maintains a relation of domination between the classes. The poorest under this system, those without property and therefore with no means of increasing their income except by what those who are rich allow them to do, end up relying on fraud simply to keep their heads above water. At the same time, she says, if wealth was allowed to move freely, i.e. without being forced into the hands of the few by unfair laws, then the resulting financial inequality would be less extreme, and not result in domination. Therefore, the stifling of freedom is both the cause and the result of extreme inequality, and this means that financial inequality is a form of domination in two ways: both in its cause and in its effects.

Grouchy investigates this further and argues that even if we were to sustain a 'natural' inequality of class, with one quarter of the income only divided equally between all citizens and the remaining three quarters divided randomly to allow for differences in wealth, this would leave a reasonably fertile country with sufficient income and property for all. She uses this point to show the role of laws in maintaining excessive inequality. If 'natural' inequality need not result in poverty, we must look, she says, to the laws and institutions of 18th century France as being responsible for causing this poverty. These laws, she says, far from being just and guaranteeing rule that is free from domination, instead represent the arbitrary will of those who are in charge. Laws and unjust institutions, she says:

alone make it the case that it is man, and not the law that dominates man; that a great function is anything other than a difficult one to fill; that it offers personal rewards other than the honour of having fulfilled it well, or glory, if its nature allows the showcasing of great talents; that other titles are required for obtaining it than services rendered and public esteem; other means to gain it than to be perceived to be worthy of it. (Bernier and Dawson, 2014: Letter 7)

Laws and institutions are thus the cause and guarantee of an economy of domination. And if laws are written that will not allow one person to interpret them at will or that will not reflect the specific interest of one group or person at a specific time, then economic exchanges should revert to justice, without causing one class to be abused or exploited while another becomes excessively rich. This in turn will increase the dignity of all, as well as their ability to live together peacefully and justly, much as Condorcet argued. But Grouchy, rather than simply going along with Condorcet's moral conclusions as drawn from economic observations, seeks to back them up by developing an argument from moral psychology, in which her claim that sympathy is the root of morality (which she draws from Smith) plays a central role.

In order to feel sympathy for a fellow human being, she argues, we must be able to think of them as somebody we could be close to, or somebody who could in some way be of benefit to us, and in any case, somebody who belongs to the same species as we do. Most people can extend their sympathy to any member of the human race - as this is a normal part of human development. However, there are ways of making sure that human beings do not see the humanity in each other, and 
this will constitute an obstacle to their being able to feel sympathy for each other, and therefore to act justly towards each other:

Virtues cannot recognize each other unless they be placed, by luck, at the same level. The powerful man and the worker in his employ are too far from each other to judge one another. And because their respective duties seem to get lost in the distance between them, the one may oppress the other nearly without remorse, while the other will in turn cheat him with impunity, even believing that he is, in this way, bringing justice to himself. The destitution of a large class of people, the sentiment of mistrust and cupidity which comes from such and leads them to cheat, makes it all the more impossible for them to be particular about the honesty of a man they buy from or sell to. Thus in all social relations, a large number of vicious institutions in that on the one hand they abused power, and on the other took away natural rights, isolated men from each other, making probity and justice useless and alien to them, by annihilating all their advantages and any reason to act on them. Thus, extreme inequality leads distant social classes no longer to regard each other as part of the same humanity. This is also, of course, the result of domination. The laws that dictate the practices sustaining this inequality are unjust laws, the purpose of which is to dominate, and oppress. The ruling classes, no matter how benign they might be in some parts of the country, always have the power to render the life of those who work for them unlivable. The solution is, then to destroy the institutions that permit such laws, and to replace them with just laws that do not aim to create extreme inequalities. (Bernier and Dawson, 2014: Letter 7)

As the last sentence of the above passage demonstrates, Grouchy believes that very little positive intervention is required in order to make a nation just. Already, she thinks, "[t]he rule of an ordinary conscience, together with reasonable laws will suffice to produce a just and good man'. And bearing in mind that she believes that free exchange will not lead to extreme poverty, it follows that very few laws will be needed to guarantee just commercial exchanges. Most of the work required will be work towards the undoing of the harm caused by previous laws and institutions - and Grouchy argues that much of this should take the form of educational reform, but also, one might suppose, the kind of positive action that would encourage those previously dominated to take charge of their own professional or commercial activities. The famine would have taught Condorcet, and through him Grouchy, that simply deregulating commercial exchange was not enough to guarantee a healthy economy.

Another distinctive feature of Grouchy's account, one that perhaps makes it more palatable to liberal minded political philosophers, is that she sees laws as moral incentives, rather than the tools of habituation. We do not need laws, she says, to teach us to be good. But bad laws disincentivize virtue, and give us reasons to act unjustly. This in turns breeds vice. Good laws, by contrast, simply allow virtue to develop naturally. They enable, rather than habituate or shape, morality. In this sense, there is a utilitarian flavour to her argument. ${ }^{13}$

The role of calculating utility is present in Grouchy's belief in the benefits of a free market for the republic. Bad laws are seen as serving the purpose of oppressing 
the poor, and their consequence is to breed vices in those who must defend themselves against them. To remove them would be to bring back a natural equilibrium which would, if not get rid of inequality altogether, at least reduce it to the extent that all are able to make a living. Utility, here, is a consideration: laws should only exist insofar as they enable all to do as well as they can. There is no need for laws to exist simply to represent an order. The leading ideal, however, is always that of republicanism: freedom from domination by arbitrary powers, even when those powers are in fact benign - as they would have been in the case of certain landowners. Free commercial exchange, in that sense, is the antithesis of economic domination: if the laws do not protect the rights of the rich against those of the poor, then it seems that the free exchange of goods and services is in principle capable of providing for the adequate survival of all (and luxury for a few). The kind of extreme inequalities that we see arising from free markets, the domination of large international chains, are the result, once again, of legislation that protects the interest of the rich, and not of the market itself. Republicanism entails that the state must legislate the market, as it does everything else, in order to avert tyrannical abuses. At least, this seems to be the view that is derived from Grouchy's discussion in Letter VII, together with what is written in the 'Observations on the King's Letter'.

\section{Conclusion}

In this article, I have argued that the insights that can be gained from studying the works of Condorcet and Grouchy are invaluable as far as understanding the relationship between late 18th-century republicanism and commercial societies is concerned. Hont identified a conflict between Rousseau's republicanism on the one hand, and his obvious interest in commercial societies on the other, and argued that in late 18th-century France this translated into a republican opposition to commercial societies. However, this was not the case for Condorcet and Grouchy. Both valued commercialism as necessary for the continued existence and growth of a republic. They argue that state regulation, or micro-management of commerce, is what brings about the bad and corrupting consequences that are so often attributed to the market. They identify market restriction as a form of domination, and make the natural assumption that a free market is a form of freedom, and that any state control that does not take the form of sensible laws is a form of tyranny, and therefore harmful to the republican character of the state. In other words, Condorcet and Grouchy did not merely accept that commercialism is compatible with republicanism, but pushed for the conclusion that the two are necessarily linked, and that one cannot be free from domination if one is not free to buy and sell the product of one's labour.

\section{Declaration of conflicting interests}

The author(s) declared no potential conflicts of interest with respect to the research, authorship, and/or publication of this article. 


\section{Funding}

The author(s) received no financial support for the research, authorship, and/or publication of this article.

\section{Notes}

1. Translations are my own, from Bergès and Schliesser (forthcoming).

2. In the 'Testament' he wrote for his daughter, Condorcet refers to the Letters, and to 'other writings ' by her mother (Lukes and Urbinati, 2012: 204).

3. Fénelon (1927 [1699, 1920]: 464-465) advocated a sort of compulsory enlightenment, a re-moulding of the character of an entire nation - and saw commerce as detrimental to this project. His critique of Louis XIV put together tyranny and luxury as the causes of corruption. Rousseau, the advocate of 'rural republicanism' also argued that urbanization, which was the result of increased trade, caused the countryside to be depleted and its values to disappear. See for instance his New Heloise (Rousseau, 1997: 438) in which he decries the exodus of younger generations of peasants to the city, and his Constitutional Project for Corsica (Rousseau, 1765) where he argues that patriotism and productivity are tied to a rural economy.

4. This went together with a certain moral distrust of commercialism. See for instance Mary Wollstonecraft's distaste for her lover's commercial activities: 'I hate commerce' she told him in a letter, to which he replied that commerce tends to 'civilize and embellish the human mind' (Gordon, 2005: 217).

5. Hont suggests that this is a misunderstanding of Rousseau (Hont, 2015: 112) and, moreover, one that may have affected the Jacobins' theorizing about the republic (Hont, 1994: 202).

6. See Bergès (2015) for a description of the contents and regarding the attribution of some of the articles to Grouchy.

7. See also Hont and Ignatief (1983: 18) on the parallels between the French and Scottish debates.

8. 'Ainsi, la liberté du commerce des grains, en assurant au peuple plus de subsistances, en les lui assurant d'une manière plus égale et plus à portée de ses facultés, le rendra encore plus nombreux, plus robuste, moins avili et moins corrompu' (Condorcet, 1776: 78).

9. Roland is perhaps better known for having been the husband of Madame Roland, the writer and philosopher who defended a Rousseau-style rural republicanism.

10. An earlier version of the argument in this article section was presented in section 4.2 of Bergès (2015).

11. My translation, from Bergès and Schliesser (forthcoming).

12. This is a premise she may have drawn from Aristotle, Politics, book VIII, 1337, a11-19, or Montesquieu, L'Esprit des Lois, Book IV, ch. 5.

13. Grouchy was connected to Bentham via her friend Dumont, who was Bentham's translator, and in correspondence with Grouchy passes on Bentham's regards to her and vice-versa. It is quite likely that their conception of economic and social 'usefulness' was in part tied to Bentham's utilitarianism. 'Utilité' features in Grouchy's Letters: criminal laws, she says in the VIIIth letter, are good insofar as they further public utility, and this is matched by their reasonableness. This is to be contrasted with laws derived from superstition and supernatural beliefs, which demand of human beings that they should behave in ways that they cannot. 


\section{References}

Bergès S (2015) Sophie de Grouchy on the cost of domination in the Letters on Sympathy and two anonymous articles in Le Républicain. The Monist 98(1): 102-112.

Bergès S and Schliesser E (forthcoming) Sophie de Grouchy's Letters on Sympathy. New York: Oxford University Press.

Bernier M-A and Dawson D (eds) (2014) Les Lettres sur la Sympathie (1798) de Sophie de Grouchy: Philosophie morale et réforme sociale. Oxford: Voltaire Foundation and Oxford University Press.

Condorcet N (1776) Le Commerce des Blés. London.

Condorcet N and Paine T (1991 [1791]) Le Républicain. In: Condorcet N and Paine T Aux origines de la République, 1789-1792. Vol. III. Paris: EDHIS.

Dagger R (2006) Neo-republicanism and the civic economy. Philosophy, Politics, Economics 5(2): $151-173$.

Fénelon F (1927 [1699, 1920]) Telemaque. Edited by A Cahen. Paris: Librairie Hachette.

Gaus G (2003) Backwards into the future: Neorepublicanism as a postsocialist critique of market society. Social Philosophy and Policy 20: 59-91.

Gordon L (2005) Vindication: A life of Mary Wollstonecraft. London: Little, Brown.

Groenewegen PD (1969) Turgot and Adam Smith. Scottish Journal of Political Economy 16(3): 271-287.

Hammersley R (2005) French Revolutionaries and English Republicans: The Cordeliers Club, 1790-1794. Martlesham: Boydell \& Brewer Ltd.

Hont I (1994) The permanent crisis of a divided mankind: 'Contemporary Crisis of the Nation State' in historical perspective. Political Studies 42: 166-231.

Hont I (2005) Jealousy of Trade. Cambridge, MA: Harvard University Press.

Hont I (2015) Politics in a Commercial Society: Jean-Jacques Rousseau and Adam Smith, Edited by. Cambridge, MA: Harvard University Press.

Hont I and Ignatief M (1983) Wealth and Virtue: The Shaping of Political Economy in the Scottish Enlightenment. Cambridge: Cambridge University Press.

Laborde C and Maynor J (2008) Republicanism and Political Theory. London: Blackwell.

Lukes S and Urbinati N (eds) (2012) Condorcet: Political Writings. Cambridge: Cambridge University Press.

Pettit P (2006) Freedom in the market. Philosophy, Politics, Economics 5(2): 131-149.

Pettit P (2013) Taking back the economy: The market as a res publica. Open Democracy. Available at: http://www.opendemocracy.net/ourkingdom/philip-pettit/taking-backeconomy-market-as-res-publica (accessed 5 March 2018).

Pocock J (1972) Virtue and commerce in the eighteenth century. Journal of Interdisciplinary History 3(1): 119-134.

Reynolds S (2013) Marriage and Revolution: Monsieur and Madame Roland. Oxford: Oxford University Press.

Rothschild E (1992) Commerce and the state: Turgot, Condorcet and Smith. The Economic Journal 102: 11971210.

Rothschild E (2013) Economic Sentiment: Adam Smith, Condorcet and the Enlightenment. Boston, MA: Harvard University Press.

Rousseau J-J (1765) Constitutional Project for Corsica. Edinburgh: Thomas Nelson and Sons Ltd.

Rousseau J-J (1997) New Heloise. Edited by J Vache. Translated by P Steward. Lebanon, NH: University Press of New England. 
Schandeler J-P and Crépel P (eds) (2004) Notes sur le Tableau Historique des progres de l'esprit humain, projets, Esquisse, Fragments et Notes (1772-1794). Paris: Institut National D'Etudes Demographiques.

Tuck R (2016) A Spokesman for his country. The Times Literary Supplement, 3 February. Available at: https://www.the-tls.co.uk/articles/private/a-spokesman-for-his-country (accessed 5 June 2018). 